\title{
Substansi Evaluasi Pendidikan dalam Perspektif Pendidikan Islam
}

\author{
Fitriani Rahayu \\ Universitas Islam Negeri Sunan Kalijaga \\ Email: fi3ani.rhy@gmail.com
}

\begin{abstract}
Islamic education aims to develop the natural potential in humans to become human beings. So that, all components in education must be accordance with the objectives of Islamic education. To find out the goal is achieved, evaluation is needed. This study uses literature studies by examining several books and leaders' thoughts, researchers will discuss more deeply about the evaluation of Islamic education both epistemology, terminology, axiology, and ontology. Evaluation can be interpreted as an effort to determine the level of success and weakness from Islamic education process, that covers all the components in it to achieve the stated goals. In the process of implementing the evaluation must apply several principles, techniques and procedures that must be followed for the good results to be obtained.
\end{abstract}

Keywords: Education Evaluation, Islamic Education, Evaluation Concept

\begin{abstract}
Abstrak
Pendidikan Islam bertujuan untuk mengembangkan potensi fitrah yang ada pada diri manusia untuk menjadi insan kamil. Sehingga semua komponen yang ada dalam pendidikan haruslah sesuai dengan tujuan pendidikan islam. Untuk mengetahui tercapai atau tidaknya tujuan tersebut, dibutuhkan evaluasi. Penelitian ini menggunakan studi literature dengan mengkaji beberapa buku dan pemikiran tokoh, peneliti akan membahas
\end{abstract}


lebih dalam tentang evaluasi pendidikan islam baik secara epistimologi, terminology, aksiologi, dan ontology. Evaluasi dapat diartikan sebagai suatu usaha yang dilakukan untuk mengetahui tingkat keberhasilan dan kelemahan suatu proses pendidikan Islam, yang mencangkup seluruh komponen yang ada didalammnya untuk mencapai tujuan yang telah ditetapkan. Dalam proses pelaksanaannya evaluasi harus menerapkan beberapa prinsip, tekhik dan prosedur yang harus di ikuti demi baiknya hasil yang akan didapatkan.

Kata Kunci: Evaluasi Pendidikan, Pendidikan Islam, Konsep Evaluasi

\section{PENDAHULUAN}

Pendidikan adalah sebuah kata yang tak asing lagi pada zaman ini. Hampir semua orang pasti sudah pernah mengenal bahkan melaksanakan pendidikan. Menurut Made Pidarta sebagaimana yang dikutip oleh Uci Sanusi dan Rudi Ahmad Suryadi menjelaskan bahwa pendidikan adalah suatu hal yang tidak dapat dipisahkan dari manusia. ${ }^{1}$ Pendidikan bukan hanya ada diantara guru dan murid ketika di sekolah saja, melainkan juga pendidikan juga ada di keluarga bahkan masyarakat. Di keluarga, Anakanak mendapatkan pendidikan dari orang tuanya. Lalu ketika sudah dewasa dan berkeluarga, maka mereka juga akan melakukan hal serupa pada anakanak mereka. Tidak ada makhluk lain yang membutuhkan pendidikan melebihi manusia.

Menurut Sisdiknas, pendidikan adalah upaya sadar dan terencana untuk mewujudkan proses belajar untuk peserta didik agar ia secara aktif dapat mengembangkan potensi dirinya untuk memiliki kekuatan spiritual keagamaan, pengendaliaan diri, kepribadian, kecerdasan, akhlak mulia, serta keterampilan yang diperlukan dalam masyarakat. ${ }^{2}$ Sedangkan menurut Ki

${ }^{1}$ Uci Sanusi and Rudi Ahmad Suryadi, Ilmu Pendidikan Islam (Yogyakarta: Deepublihs, 2018). h. 2.

${ }^{2}$ Undang-Undang SISDIKNAS No 20 Tahun 2003 tentang Sistem Pendidikan Nasional. 
Hajar Dewantara selaku bapak pendididkan nasional menjelaskan bahwa pendidikan adalah tuntutan di dalam hidup tumbuhnya anak-anak. Maksudnya adalah dengan pendidikan, anak-anak dituntut untuk menjadi anggota masyarakat yang dapat mencapai keselamatan dan kebahagiaan setinggi-tingginya.

Dalam pendidikan Islam, pendidikan bertujuan untuk membentuk insan kamil atau manusia paripurna. Tujuan pendidikan ini merupakan inti dari segala proses pendidikan. Sehingga segala komponen dalam pendidikan Islam seperti kurikulum, metode, dan proses yang berlangsung harus selalu disesuaikan dengan tujuan pendidikan Islam. Namun, pertanyaannya adalah apakah pendidikan islam telah berhasil dalam praktiknya di lapangan ? Sejauh mana pencapaian yang telah diperoleh pendidikan islam dalam kaitannya dengan pembentukan insan kamil? Kendala apa saja yang dihadapi dalam proses pendidikan islam untuk mencapai tujuannya?. Jawaban terhadap pertanyaan ini hendaknya terungkap melalui proses evaluasi yang dilakukan terhadap pendidikan islam. ${ }^{3}$

Begitulah letak pentingnya proses evaluasi dalam pendidikan. Dalam pelaksanaannya, evaluasi harus memperhatikan berbagai hal seperti tujuan dan fungsi dari evaluasi, objek evalusai, prinsip evaluasi, tehnik dan prosedur evaluasi itu sendiri. Sehingga dengan demikian diharapkan evaluasi dapat meningkatkan mutu pendidikan.

\section{METODE PENELITIAN}

Penelitian ini merupakan penelitian kepustakaan (library research) dengan menggunakan dokumen sebagai alat pengumpulan data. Dalam penelitian ini, peneliti menggunakan buku dari pemikiran beberapa tokoh untuk menjabarakan evaluasi pendidikan islam baik secara terminology, epistimology aksiology, dan ontology dengan mengkaji lebih dalam tentang hakikat evaluasi pendidikan islam, landasan evaluasi pendidikan islam,

\footnotetext{
${ }^{3}$ Syamsul Nizar, Filsafat Pendidikan Islam Pendekatan Historis, Teoritis, Dan Praktis (Jakarta: Ciputat Press, 2002). Hal 79.
} 
tujuan dan fungsi evaluasi pendidikan Islam, objek evaluasi pendidikan islam, prinsip evaluasi pendidikan islam, tehnik evaluasi, dan prosedur pelaksanaan evaluasi.

\section{HASIL PENELITIAN}

\section{Hakikat Evaluasi Pendidikan Islam}

Salah satu komponan yang penting untuk melihat keberhasilan dalam pendidikan adalah evaluasi. Berhasil atau tidaknya pendidikan islam dalam mencapai tujuannya, dapat dilihat setelah dilakukan evaluasi terhadap output yang dihasilkan. ${ }^{4}$ Jika hasilnya sesuai dengan apa yang ditetapkan dalam tujuan pendidikan islam, maka usaha pendidikan itu dapat dinilai berhasil. Namun jika yang terjadi sebaliknya, maka evaluasi dinilai gagal. Oleh karena itu, evaluasi dapat diartikan sebagai suatu usaha untuk mengetahui tingkat keberhasilan pendidikan yang meliputi seluruh komponennya dalam mencapai tujuan pendidikan yang telah ditetapkan. ${ }^{5}$

Menurut Kurniawan konsep evaluasi dalam pendidikan memiliki makna ganda yaitu: ${ }^{6}$

1. Evaluasi ditempatkan sebagai salah satu aktivitas epistimologi pendidikan islam yang berguna untuk "mengetahui" seberapa banyak hasil yang diperoleh dalam proses pendidikan.

2. Evaluasi ditempatkan sebagai aksiologi pendidikan islam yang berguna untuk "memberi muatan nilai" dalam setiap komponen dan proses pendidikan.

Sedangkan menurut Lembaga Administrasi Negara, Evaluasi Pendidikan sebagai berikut: ${ }^{7}$

${ }^{4}$ Jalaluddin, Filsafat Pendidikan Islam (Jakarta: Raja Grafindo Persada, 1994). Hal 60.

${ }^{5}$ Syamsul Nizar, Filsafat Pendidikan Islam Pendekatan Historis, Teoritis, Dan Praktis. h. 77.

${ }^{6}$ Syamsul Kurniawan, Ilmu Pendidikan Islam Sebuah Kajian Komprehensif (Yogyakarta: Penerbit Ombak, 2016).

${ }^{7}$ Anas Sudjiono, Pengantar Evaluasi Pendidikan (Jakarta: Raja Grafindo Persada, 2016). h. 2. 
1. Evaluasi Pendidikan adalah proses/kegiatan untuk menentukan kemajuan pendidikan, dibandingkan dengan tujuan yang telah di tentukan.

2. Evaluasi Pendidikan merupakan usaha untuk memperoleh informasi berupa umpan balik (feed back) bagi penyempurnaan pendidikan.

Menurut Abdul Mujib, Evaluasi Pendidikan Islam adalah suatu kegiatan untuk menentukan taraf kemajuan suatu aktivitas di dalam pendidikan Islam.

Kata evaluasi berasal dari berbahasa Inggris to evaluation yang berarti "menilai". ${ }^{8}$ Sedangkan dalam bahasa Arab evaluasi dikenal dengan istilah imtihan yang berarti "ujian" dan khataman yang berarti cara menilai hasil akhir dari proses pendidikan. ${ }^{9}$ Evaluasi merupakan tindak lanjut yang dilakukan untuk mengetahui sejauh mana pelajaran yang disampaikan oleh pendidik dapat dipahami oleh peserta didik. Evaluasi dapat dilakukan setiap hari, setiap bulan, setiap semester, dan bahkan ada evaluasi tahap akhir.

Dengan evaluasi, pendidik dapat memetakan tingkat kemampuan peserta didik dalam suatu pelajaran, mana peserta didik yang berkemampuan tinggi, sedang dan tertinggal. Sehingga, setelah diketahuinya kemampuan peserta didik, pendidik dapat memberikan treatment terhadap peserta didik. Peserta didik yang lemah diberi perhatian khusus agar ia dapat mengejar dan memenuhi kekurangannya, sedangkan kepada yang cerdas diberikan pengayaan agar ia terus meningkatkan kemampuannya kearah yang lebih baik lagi. Inilah gambaran tentang evaluasi pendidikan yang dilakukan dilembaga formal di Indonesia.

Dalam evaluasi pendidikan islam, evaluasi tidak hanya sebatas penilaian yang dimunculkan dengan angka-angka, melainkan lebih dari itu. ${ }^{10}$ Menurut Daulay suatu hal yang paling esensi dari evaluasi adalah

${ }^{8}$ Syamsul Kurniawan, Ilmu Pendidikan Islam Sebuah Kajian Komprehensif. h. 174.

${ }^{9}$ Abuddin Nata, Filsafat Pendidikan Islam 1 (Jakarta: Logos Wacana Ilmu, 1997). h. 131 .

${ }^{10}$ Haidar Putra Daulay, Pendidikan Islam Dalam Perspektif Filsafat (Jakarta: Kencana, 2014). h. 130. 
seseorang dapat mengevaluasi dirinya sendiri. Yakni sudah seberapa jauh kemampuan beragamanya, keimanannya, dan pengalaman agama serta akhlak mulia. Orang yang menyadari dirinya masih banyak kekurangan maka ia akan berupaya untuk memperbaiki dirinya sendiri. Jadi sesungguhnya evaluasi dalam pandangan pendidikan islam itu menitikberatkan pada pembentukan kesadaran diri setelah mengetahui apa saja yang harus diperbaiki dalam perjalanan hidupnya. Menumbuhkan sikap mental yang demikian itulah hakikat dari evaluasi dalam konsep pendidikan Islam.

\section{Landasan Evaluasi Pendidikan Islam}

Evaluasi pendidikan islam dilaksanakan berdasarkan dua pedoamn yaitu Al-Quran dan Hadist. Ada banyak dalil terutama surah dalam AlQuran yang membicarankan tentang evaluasi sebagai berikut:

1. Dalam Al-Qur'an surat Al-Hasyr ayat 18 Allah Swt berfirman:

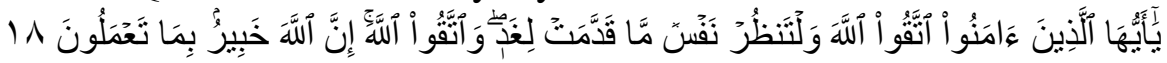

Terjemahnya:

"Hai orang-orang yang beriman, bertakwalah kepada Allah dan hendaklah setiap diri memperhatikan apa yang telah diperbuatnya untuk hari esok (akhirat); dan bertakwalah kepada Allah, sesungguhnya Allah Maha Mengetahui apa yang kamu kerjakan.”

Dalam hal ini bertakwa kepada Allah pada redaksi pertama dikaitkan dengan suatu sikap yang harus dimiliki oleh setiap manusia beriman agar senantiasa melakukan evaluasi terhadap perbuatannya yang telah lalu yang akan menjadi dasar dalam melakukan perbuatan selanjutnya.

2. Di dalam hadist Nabi disebutkan:

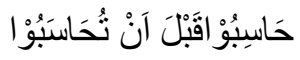

Artinya:

"evaluasilah dirimu sebelum engkau dievaluasi."

Pernyataan ini berkaitan dengan kegiatan evaluasi terhadap diri sendiri. hal ini membuktikan bahwa Allah mengutus dua malaikat, yaitu Raqib dan Atid sebagai supervisor dan evaluator manusia. Kedua malaikat tersebut mencatat semua perbuatan manusia. Berdasarkan catatan tersebut 
Allah mengevaluasinya. Hasil penilaian yang baik mendapatkan surga sedangkan hasil penilaian yang buruk mendapatkan neraka.

3. Allah juga berfirman di dalam al-Qur'an surah Al-Ghashiyah : 26 نُمُُّ إِنَّ عَلَيْنَا حِسَابَهُم

Terjemahnya:

"Kemudian sesungguhnya kewajiban Kamilah menghisab mereka".

4. Dan di dalam Al-Quran surah al-Zilzalah ayat 7-8 Allah berfirman:

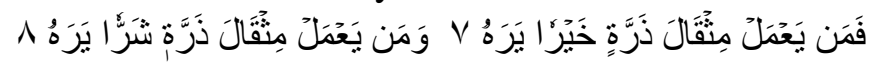

Terjemahnya:

"Barangsiapa yang mengerjakan kebaikan seberat dzarrahpun, niscaya dia akan melihat (balasan)nya. Dan barangsiapa yang mengerjakan kejahatan sebesar dzarrahpun, niscaya dia akan melihat (balasan)nya pula"

Dari ayat-ayat di atas dapat dipahami bahwasannya setiap manusia akan dihisab sesuai dengan amal perbuatannya, baik dari kebaikan maupun kejelekannya walaupun seberat dzarrah. Maka sepantasnya setiap manusia untuk selalu mengevaluasi dirinya sendiri. Sebelum allah mengevaluasi amal perbuatannya.

\section{Tujuan dan Fungsi Evaluasi Pendidikan Islam}

Dalam makalah ini, penulis akan membedakan tujuan dan fungsi evaluasi menjadi dua yaitu ditinjau dari segi umum dan tujuan dan dari segi khusus. Berikut penjabarannya:

1. Tujuan dan Fungsi Evaluasi Pendidikan Islam (Umum)

Pendidikan Islam secara rasional-filosofis adalah bertujuan untuk membentuk al-insan al-kamil atau manusia paripurna. ${ }^{11}$ Beranjak dari konsep ini, pendidikan Islam hendaknya diarahkan pada dua dimensi, yaitu: Pertama, dimensi horizontal dan kedua, dimensi vertical. ${ }^{12}$ Pada dimensi horizontal pendidikan hendaknya dapat mengembangkan pemahaman tentang kehidupan konkrit yang terikat dengan diri, sesama manusia dan

\footnotetext{
${ }^{11}$ Zakiyah Daradjat, Ilmu Pendidikan Islam (Jakarta: Bumi Aksara, 2014). h. 31.

${ }^{12}$ Syamsul Nizar, Filsafat Pendidikan Islam Pendekatan Historis, Teoritis, Dan Praktis. h. 78 .
} 
alam semesta. Untuk itu akumulasi berbagai pengetahuan, keterampilan, dan sikap mental merupakan bekal utama dalam hubungan ini. Sedangkan pada dimensi vertikal, selain menjadi alat untuk melestarikan sumber daya alami, pendidikan juga hendaknya menjadi jembatan dalam mencapai hubungan yang abadi dengan pencipta.

Secara umum dimensi vertikal dan horizontal tersebut merupakan tujuan dan fungsi dari evaluasi pendidikan Islam. Lebih dalam lagi, menurut Abuddin Nata tujuan dari evaluasi menurut ajaran islam berdasarkan pemahaman terhadap ayat-ayat al-Quran adalah untuk menguji kemampuan tingkat keimanan manusia dalammenghadapi berbagai problem kehidupan, untuk mengetahui sejauh mana hasil pendidikan Al-Quran yang telah ditetapkan rasulullah kepada umatnya, dan untuk menentukan klasifikasi atau tingkatan hidup dan keimanan manusia. ${ }^{13}$ Untuk mengetahui sejauh mana kuatnya iman seseorang, Allah terkadang mengevalusainya melalui berbagai cobaan yang besar. Allah berfirman:
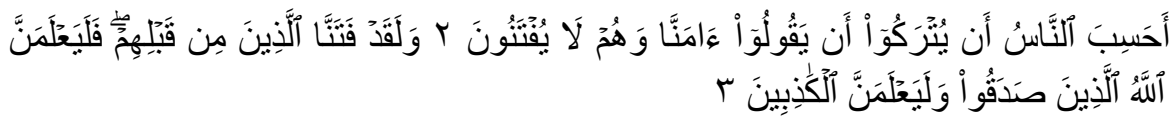

Terjemahnya:

“ (2) Apakah manusia itu mengira bahwa mereka dibiarkan (saja) mengatakan: 'Kami telah beriman', sedang mereka tidak diuji lagi. (3) Dan sesungguhnya kami telah menguji orang-orang yang sebelum mereka, maka sesungguhnya Allah mengetahui orang-orang yang benar dan sesungguhnya Dia mengetahui orang-orang yang dusta." (QS. al-Ankabut : 2-3)

Pada ayat tersebut dengan tegas dinyatakan bahwa Allah akan menguji kualitas keimanan seseorang dengan berbagai evaluasi atau cobaan. Dengan demikian dapat diketahui siapa saja yang menetap imannya dan yang imannya palsu.

\footnotetext{
${ }^{13}$ Abuddin Nata, Filsafat Pendidikan Islam 1. h. 137.
} 
2. Tujuan dan Fungsi Pendidikan Islam (Khusus)

Secara khusus, tujuan pelaksanaan evaluasi dalam pendidikan Islam adalah untuk mengetahui pemahaman peserta didik terhadap materi pelajaran, baik dalam aspek kognitif, psikomotorik maupun afektif. Namun dalam pendidikan Islam, tujuan evaluasi lebih ditekankan pada penguasaan sikap (afektif dan psikomotor) ketimbang aspek kognitif. ${ }^{14}$ Penekanan ini bertujuan untuk mengetahui kemampuan peserta didik yang secara garis besarnya meliputi empat hal yaitu $:^{15}$

- Sikap dan pengalaman terhadap hubungan pribadinya dengan tuhan

- Sikap dan pengalaman terhadap arti hubungan dirinya dengan masyarakat

- Sikap dan pengalaman terhadap arti hubungan kehidupannya dengan alam sekitar

- Sikap dan pandangan terhadap diri sendiri selaku hamba Allah, anggota masyarakat, serta khalifah Allah SWT.

Seluruh tujuan tersebut dapat dicapai melalui pelaksanaan evaluasi yang mengacu pada prinsip-prinsip al-Quran dan Sunah disamping menganut prinsip objektifitas, kontinunitas dan komperhensif. Sedangkan operasionalisasinya di lapangan dapat saja dilakukan melalui berbagai bentuk evaluasi, test atau non test, lisan atau tulisan, pre test atau post tes, dan lain sebagainya.

Menurut Suharsimi Arikunto tujuan dan fungsi evaluasi dibagi menjadi empat. Berikut penejalasannya. ${ }^{16}$

a. Evaluasi berfungsi selektif. Penilaian ini sendiri berfungsi untuk memilih siswa yang dapat diterima di sekolah tertentu, memilih siswa yang dapat naik kelas, memilih siswa yang seharusnya mendapat beasiswa, dan memilih siswa yang sudah berhak meninggalkan sekolah, dan sebagainya.

${ }^{14}$ Jalaluddin, Filsafat Pendidikan Islam. h. 60.

15 Syamsul Nizar, Filsafat Pendidikan Islam Pendekatan Historis, Teoritis, Dan Praktis. h. 80.

${ }^{16}$ Suharsimi Arikunto, Dasar-Dasar Evaluasi Pendidikan (Jakarta: Bumi Aksara, 2012). h. 18-19. 
b. Evaluasi berfungsi diagnostic. Dengan melakukan penilaian, maka guru akan mengetahui kelemahan dan kelebihan siswa beserta penyebabnya. Sehingga hal ini akan mempermudah untuk mengatasinya.

c. Evaluasi berfungsi sebagai penempatan. Untuk menentukan dengan pasti di kelompok mana seseorang siswa harus ditempatkan, maka disinilah fungsinya penilaian.

d. Evaluasi berfungsi sebagai pengukur keberhasilan. Sedangkan fungsi ini adalah untuk mengetahui sejauh mana suatu program berhasil diterapkan.

Sedangkan lebih spesifik lagi, Sukardi dalam bukunya Evalusi Pendidikan mengemukakan tujuan dan fungsi evaluasi sebagai berikut $:^{17}$

a. Menilai ketercapaian tujuan. Dalam pendidikan, tujuan belajar, metode evaluasi, dan cara belajar siswa saling terkait satu sama lain. Cara belajar siswa biasanya ditentukan oleh cara evaluasi, begitupula sebaliknya metode evaluasi yang digunakan guru ditentukan oleh tujuan evaluasi.

b. Mengukur macam-macam aspek belajar yang bervariasi. Belajar dikategorikan sebagai kognitif, psikomotorik, dan afektif.

c. Sebagai sarana untuk mengetahui apa yang siswa telah ketahui. Setiap orang masuk kelas dengan membawa pengalamannya masing-masing.

d. Memotivasi belajar siswa. Evaluasi juag harus dapat memotivasi belajar siswa. Guru harus menguasai bermacam-macam teknik motivasi, tetapi masih sedikit di antara para guru yang mengetahui teknik motivasi yang berkaitan dengan evaluasi.

e. Menyediakan informasi untuk tujuan bimbingan dan konseling. Informasi diperlukan jika bimbingan dan konseling yang efektif diperlukan, infomasi yang berkaitan dengan problem pribadi seperti

17 Sukardi, Evaluasi Pendidikan: Prinsip Dan Oprasionalnya (Jakarta: Bumi Aksara, 2008). h. 8-9. 
data kemampuan, kualitas pribadi, adaptasi sosial, kemampuan membaca dan skor hasil belajar.

f. Menjadikan hasil evaluasi sebagai dasar perubahan kurukulum.

\section{Objek Evaluasi Pendidikan Islam}

Umumnya, dapat diartikan objek dari evaluasi pendidikan Islam adalah peserta didik. Sementara secara khusus, objek evaluasi meliputi aspek-aspek tertentu yang terdapat pada peserta didik. Pada hakikatnya, peserta didik bukan hanya berperan sebagai objek evaluasi semata, melainkan juga berperan sebagai subjek evaluasi. Oleh karna itu, evaluasi pendidikan lslam dapat dilakukan dengan dua cara, yaitu evaluasi diri sendiri (self evaluation/introspeksi) dan evaluasl terhadap orang lain atau peserta didik. $^{18}$

Evaluasi ini tentunya berdasarkan kesadaran internal yang bertujuan untuk meningkatkan kreativitas dan produktivitas (amal saleh) pribadi. Jika dalam evaluasi ditemukan keberhasilan, maka hendaklah keberhasilan tersebut di pertahankan dan ditingkatkan. Akan tetapi apabila ditemukan beberapa kelemahan dan kegagalan, maka hendaknya hal tersebut segera diperbaiki dengan cara meningkatkan ilmu, iman, dan amal. ${ }^{19}$

Umar bin Khatab berkata "haasibuu qabla an tuhaasabuu" (evaluasilah dirimu sebelum engkau dievaluasi). Pernyataan ini berkaitan dengan kegiatan evaluasi terhadap diri sendiri. Asumsi yang mendasari pernyataan tersebut adalah bahwa Allah mengutus dua malaikat Raqib dan Atid sehagai supervisor den evaluator terhadap manusia. Kedua malaikat tersebut mencatat semua perbuatan manusia. Berdasarkan catatan tersebut, Allah kemudian mengevaluasinya. Hasil yang baik mendapatkan surga, sedangkan hasil yang buruk mendapatkan neraka. Karena itu, manusia dituntut untuk selalu waspada dan memperhitungkan segala tindakannya, agar kehidupannya kelak tidak merugi.

178.

${ }^{18}$ Syamsul Kurniawan, Ilmu Pendidikan Islam Sebuah Kajian Komprehensif. h.

${ }^{19}$ Syamsul Kurniawan, Ilmu Pendidikan Islam Sebuah Kajian Komprehensif. h. 178. 
Salah seorang tokoh pendidikan islam yang pernah melaksanakan evaluasi pendidikan islam dengan cara diatas adalah Hasan Al-Banna pendiri Ikhwan al-Muslim di Mesir. ${ }^{20}$ Ia menerapkan evaluasi dengan cara terhadap dirinya sendiri dan kepada seluruh peserta didiknya setiap hari. Hal ini didasarkan pada prinsip amar makruf nahi munkar yang bertujuan untuk perbaikan sesama umat islam.

\section{Prinsip Evaluasi Dalam Pendidikan Islam}

Dalam melakukan evaluasi, ada beberapa prinsip yang perlu diperhatikan. Betapapun baiknya prosedur evaluasi diikuti dan sempurnanya tehnik evaluasi diterapkan, namun apabila tidak dipadukan dengan prinsipprinsip penunjangnya maka hasil evaluasi pun akan kurang dari yang diharapkan. Menurut Daryono prinsip-prinsip yang dimaksud adalah sebagai berikut: ${ }^{21}$

1. Keterpaduan, yang meliputi tujuan instruksional, materi dan metode pengajaran yang tidak boleh dipisahkan. Karena itu, perencanaan evaluasi harus sudah diterapkan pada waktu menyusun RPP sehingga dapat disesuaikan secara harmonis dengan tujuan instruksional dan materi pengajaran yang hendak disajikan.

2. Keterlibatan Siswa. Siswa dituntut untuk terlibat secara aktif sebagaimana yang diterapkan oleh metode belajar CBSA (cara belajar siswa aktif). Untuk mengetahui sejauh mana keterlibatan siswa dalam pembelajaran maka diperlukan evaluasi. Oleh karena itu evaluasi bagi siswa merupakan kebutuhan yang harus terpenuhi.

3. Koherensi. Dengan prinsip koherensi yang dimaksud evaluasi harus berkaitan dengan materi pengajaran yang sudah disajikan dan disesuaikan dengan ranah kemampuan yang hendak diukur. Tidak dapat dibenarkan menyusun alat evaluasi hasil belajar atau evaluasi pencapaian belajar yang mengukur bahan yang belum disajikan dalam kagiatan belajar-mengajar. Demikian pula tidak diterima apabila alat

${ }^{20} \mathrm{Abu}$ Muhammad Iqbal, Pemikiran Pendidikan Islam (Yogyakarta: Pustaka Pelajar, 2015). h. 436.

${ }^{21}$ Daryanto, Evaluasi Pendidikan (Jakarta: Rineka Cipta, 2012). h. 19-21. 
evaluasi berisi butir yang tidak berkaitan dengan bidang kemampuan yang hendak diukur.

4. Pedagogis. Selain sebagai alat penilai, evaluasi perlu diterapkan sebagai langkah dalam memperbaiki sikap dan tingkah laku secara pedagogis. Evaluasi dan hasilnya hendaknya dapat dipakai sebagai alat motivasi unsur siswa dalam kegiatan belajarnya. Hasil evaluasi hendaknya dirasakan sebagai ganjaran yakni sebagai penghargaan bagi yang tidak / kurang berhasil.

5. Akuntabilitas. Sejauh mana keberhasilan program pengajaran perlu disampingkan kepada pihak-pihak yang berkepentingan dengan pendidikan diantranya adalah siswa, orang tua, masyarakat, dan lembaga pendidikan sendiri. Hal ini dipandang perlu sebagai laporan pertanggungjawaban kepada pihak terkait sehingga dapat dipertimbangkan pemanfaatannya.

Sedangkan menurut Abudin Nata dalam bukunya Filasafat Pendidikan Islam mengungkapkan bahwa ada enam prinsip dalam evaluasi pendidikan: ${ }^{22}$

1. Evaluasi hendaknya didasarkan atas hasil pengukuran yang komperhensif. Yaitu pengukuran yang meliputi aspek kognitif, afektif, dan psikomotorik.

2. Evaluasi harus dibedakan antara penskoran dengan angka dan penilaian dengan kategori. Penskoran berkenan dengan aspek kuantitatif dan penilaian berkenan dengan aspek kualitatif.

3. Dalam proses pemberian nilai hendaknya diperhatikan dua macam penilaian, yaitu penilaian yang berkenan dengan hasil belajar dan penempatan peserta didik.

4. Pemberian nilai hendaknya merupakan bagian integral dari proses belajar-mengajar.

5. Penilaian hendaknya bersifat komparabel atau dapat dibandingkan antara satu tahap penilaian dengan tahap lainya.

\footnotetext{
${ }^{22}$ Abuddin Nata, Filsafat Pendidikan Islam 1. h. 140.
} 
6. Sistem penilaian yang dipergunakan hendaknya jelas bagi siswa dan bagi pengajar sendiri, sehingga tidak membingungkan.

Sedangkan menurut Abdul Aziz dalam bukunya Filsafat pendidikan Islam, prinsip-prinsip demi berhasilnya evaluasi sebagai berikut $:^{23}$

1. Evaluasi harus mengacu kepada tujuan. Agar evaluasi sesuai dan dapat mencapai sasaran, maka evaluasi harus mengacu kepada tujuan pendidikan.

2. Evaluasi dilaksanakan dengan objektif. Artinya, evaluasi itu dilaksanakan dengan sebaik-baiknya, berdasarkan fakta dan data yang ada tanpa dipengaruhi oleh unsure-unsur subjektifitas dari evaluator.

3. Evaluasi harus dilakukan dengan komperhensif. Evaluasi ini dalam artian harus dilakukan harus dilalukan secara menyeluruh, meliputi berbagai aspek kehidupan peserta didik didik, baik yang menyangkut iman, ilmu dan amalnya.

4. Evaluasi harus dilaksanakan secara berkesinambungan (kontinuitas). Prinsip yang terakhir ini harus mengadakan evaluasi secara terus menerus akan tetapi tidak boleh meninggalkan prinsip evaluasi yang lainnya.

\section{Tehnik Evaluasi}

Dalam evalusai, secara garis besar ada dua macam tehnik tes yaitu tes dan non tes. Berikut penjelasannya: ${ }^{24}$

1. Tehnik Tes

Ditinjau dari segi kegunaannya untuk mengukur siswa, maka tes dibagi menjadi tiga yaitu tes diagnostic, tes formatif, dan tes sumantif.

- Tes diagnostic berguna untuk mengetahui kelemahan-kelemahan siswa baik berupa kesulitan belajar maupun hambatan yang didalami oleh peserta didik, sehingga dapat diberikan penanganan yang tepat. Tes ini biasanya dilakukan secara lisan ataupun tulisan.

${ }^{23}$ Abdul Aziz, Filsafat Pendidikan Islam Sebuah Gagasan Membangun Pendidikan Islam (Yogyakarta: Sukses Offset, 2009). h. 170.

${ }^{24}$ Suharsimi Arikunto, Dasar-Dasar Evaluasi Pendidikan. 
- Tes formatif yang bertujuan untuk mengetahui sejauh mana siswa terbentuk setelah mengikuti program tertentu. Tes ini dilaksanakan biasanya di tengah-tengah perjalanan program pembelajaran dan disebut dengan "ujian harian".

- Tes sumantif adalah tes akhir dari program pembelajaran. Tes ini bisa disebut EBTA, tes akhir semestes, UAN. Materinya yang di tes adalah materi yang telah diajar kan selama satu semester.

2. Tehnik Non Tes

Suharsimi Arikunto membedakan tehnik non tes menjadi 6 macam, di antaranya adalah skala bertingkat, kuisioner, daftar cocok, wawancara, observasi, dan riwayat hidup.

- Skala bertingkat menggambarkan suatu nilai yang berbentuk angka terhadap sesuatu hasil pertimbangan

- Kuisioner atau yang lebih dikenal dengan angket adalah sebuah draf pertanyaan yang harus diisi oleh orang yang akan diukur.

- Daftar Cocok adalah deretan pertanyaan, dimana responden yang dievaluasi tinggal membubuhkan tanda cocok ditempat yang sudah disediakan.

- Wawancara atau interview adalah suatu metode atau cara yang digunakan untuk mendapatkan jawaban dari responden dengan cara tanya jawab sepihak.

- Observasi atau pengamatan adalah suatu tehnik yang dilakukan dengan mengadakan pengamatan secara teliti serta pencatatan secara sistematis.

- Riwayat hidup adalah gambaran tentang keadaan seseorang selama masa kehidupannya. Sehingga dengan mengetahui riwayat hidup subyek, maka akan mempermudah kegiatan evaluasi.

\section{Prosedur Pelaksanaan Evaluasi}

Dalam melakukan evaluasi, ada beberapa prosedur atau langkahlangkah yang perlu diperhatikan demi berhasilnya suatu kegiatan evaluasi. 
Berikut dikemukakan prosedur pelaksanaan evaluasi menurut Zaenal Arifin. ${ }^{25}$

1. Perencanaan Evaluasi, adalah langkah pertama yang perlu dilakukan dalam kegiatan evaluasi. Dalam perencanaan ada beberapa faktor yang harus diperhatikan diantaranya adalah merumuskan tujuan penilaian, mengidentifikasi kompetensi dan hasil belajar, menyusun kisi-kisi, mengembangkan draf instrument, uji coba dan analisis instrument, revisi dan merakit instrument baru.

2. Pelaksanaan Evaluasi. Pelaksanaan evaluasi sangat bergantung dari jenis evaluasi yang digunakan. Karena hal ini akan berdampak pada penentuan prosedur, metode, instrument, waktu pelaksanaan, sumber data, dan sebagainya. Dalam pelaksanaan penilaian hasil belajar, guru dapat menggunakan tes (tes pelaksanaan penilaian hasil belajar) maupun non tes 9angket, observasi, wawancara, studi dokumentasi, skala sikap, dan sebagainya).

3. Monitoring Pelaksanaan Evaluasi, digunakan untuk memantau pelaksanaan evaluasi agar tetap sesuai dengan perencanaan evaluasi yang telah ditetapkan sebelumnya. Fungsi monitoring ada 2 yaitu untuk melihat relevansi pelaksanaan evaluasi dengan perencanaan evaluasi, dan untuk melihat hal apa yang terjadi selama pelaksanaan evaluasi.

4. Pengolahan Data. Mengolah data berarti mengubah sujud data yang sudah terkumpul menjadi sebuah sajian menarik dan bermakna. Data evaluasi ada dua jenis,kualitatif dan kuantitatif. Data yang berbentuk kualitatif tentu dianalisis secara kualitatif, begitupula yang kuantitatif.

5. Pelaporan Hasil Evaluasi. Sebagai bentuk akuntabilitas publik, pihakpihak yang berkepentingan seperti orang tua/wali, kepala sekolah, pengawas, pemerintah, mitra sekolah, dan peserta didik itu sendiri harus menerima laporan hasil dari evaluasi.

6. Penggunaan Hasil Evaluasi. Tahap akhir dalam evaluasi adalah penggunaan atau pemanfaatan hasil evaluasi. Salah satu pengunaan

${ }^{25}$ Zaenal Arifin, Evaluasi Pembelajaran: Prinsip, Tehnik, Prosedur (Bandung: Remaja Rosdakarya, 2009). h. 88-166. 
hasil evaluasi adalah laporan. Laporan yang dimaksud untuk memberi feedback kepada semua pihak yang terlibat dalam pembelajaran, baik secara langsung maupun tidak langsung.

\section{KESIMPULAN}

Secara umum evaluasi adalah suatu usaha yang dilakukan untuk mengetahui tingkat keberhasilan dan kelemahan suatu proses pendidikan islam (dengan seluruh komponen yang terlibat di dalamnya) dalam mencapai tujuan pendidikan yang dicita-citakan. Tujuan pendidikan adalah membentuk insan kamil. Oleh karena itu, untuk mengetahui apakah tujuan dari pendidikan islam ini telah tercapai atau tidak maka diperlukan evaluasi. Evaluasi berguna untuk mengetahui kuantitas dan kualitas dari seseorang yang perlu diadakan evaluasi. Selain itu, dalam evaluasi perlu diperhatikan beberapa prinsip seperti obyeksitas, kesinambungan, dan komperhensif atau keseluruhan.

Peserta didik bukan hanya merupakan objek dari evaluasi, melainkan juga berkedudukan sebagai subjek evaluasi. Hasan Al-Banna merupakan tokoh pertama yang menggagas konsep evaluasi dalam pendidikan. Ia menerapkan evaluasi dengan cara terhadap dirinya sendiri dan kepada seluruh peserta didiknya setiap hari. Hal ini didasarkan pada prinsip amar makruf nahi munkar yang bertujuan untuk perbaikan sesama umat islam

Jika makna evaluasi lebih diperdalam, dalam pandangan islam evaluasi ini merupakan ujian yang diberikan oleh Allah untuk mengetahui kadar keimanan seorang hamba. Sebagaimana firmannya dalam Quran surah al-Ankabut Allah berfirman bahwa setiap yang beriman harus diuji. Selain itu, disebutkan juga tugas dari malaikat Raqib dan Atid adalah mencatat semua amal perbuatan manusia untuk akhirnya dilakukan evaluasi oleh Allah. 


\section{DAFTAR PUSTAKA}

Abdul Aziz. Filsafat Pendidikan Islam Sebuah Gagasan Membangun Pendidikan Islam. Yogyakarta: Sukses Offset, 2009.

Abu Muhammad Iqbal. Pemikiran Pendidikan Islam. Yogyakarta: Pustaka Pelajar, 2015.

Abuddin Nata. Filsafat Pendidikan Islam 1. Jakarta: Logos Wacana Ilmu, 1997.

Anas Sudjiono. Pengantar Evaluasi Pendidikan. Jakarta: Raja Grafindo Persada, 2016.

Daryanto. Evaluasi Pendidikan. Jakarta: Rineka Cipta, 2012.

Haidar Putra Daulay. Pendidikan Islam Dalam Perspektif Filsafat. Jakarta: Kencana, 2014.

Jalaluddin. Filsafat Pendidikan Islam. Jakarta: Raja Grafindo Persada, 1994.

Suharsimi Arikunto. Dasar-Dasar Evaluasi Pendidikan. Jakarta: Bumi Aksara, 2012.

Sukardi. Evaluasi Pendidikan : Prinsip Dan Oprasionalnya. Jakarta: Bumi Aksara, 2008.

Syamsul Kurniawan. Ilmu Pendidikan Islam Sebuah Kajian Komprehensif. Yogyakarta: Penerbit Ombak, 2016.

Syamsul Nizar. Filsafat Pendidikan Islam Pendekatan Historis, Teoritis, Dan Praktis. Jakarta: Ciputat Press, 2002.

Uci Sanusi, and Rudi Ahmad Suryadi. Ilmu Pendidikan Islam. Yogyakarta: Deepublihs, 2018. 
121 | Fitriani Rahayu

Zaenal Arifin. Evaluasi Pembelajaran: Prinsip, Tehnik, Prosedur. Bandung: Remaja Rosdakarya, 2009.

Zakiah Daradjat. Ilmu Pendidikan Islam. Jakarta: Bumi Aksara, 2014. 